Springer Link

Search $Q$

- $\underline{\log } \underline{\text { in }}$

Search SpringerLink

Search $Q$

- Original Research Article

- Published: 31 August 2020

\title{
Evaluation of the prescribing of proton pump inhibitors as stress ulcer prophylaxis for non-ICU patients in a Malaysian tertiary hospital
}

- $\underline{\text { Muhammad Eid Akkawi }} \square$ ORCID: orcid.org/0000-0001-9964-0355 1 , $\underline{2}$ \&

- $\underline{\text { Mohamed Hassan Elnaem ORCID: orcid.org/0000-0003-0873-6541 }}$ 1,2

Drugs \& Therapy Perspectives (2020) Cite this article

- 11 Accesses

- 1 Altmetric

- Metrics details

\section{Abstract}

\section{Background}

Proton pump inhibitors (PPIs) are widely prescribed in hospital settings. Several reports have highlighted concerns about the inappropriate use of PPIs as stress ulcer prophylaxis (SUP) in patients outside the intensive care unit (ICU) setting. Little is known about this phenomenon in Malaysian hospitals.

We use cookies to personalise content and ads, to provide social media features and to analyse our traffic. We also share information about your use of our site with our social media, advertising and analytics partners in accordance with our Privacy Statement. You can manage your preferences in Manage Cookies. 


\section{Results}

Of 660 screened patients admitted to the general medical wards, 200 were prescribed PPIs as SUP. Oral pantoprazole was the most frequently prescribed PPI (51.5\%). Only 61 (30.5\%) PPIs were prescribed according to current recommendations for the use of PPI for SUP. Sex, age, number of medications, length of hospital stay, and receiving PPI at discharge were not significantly associated with appropriateness of PPI prescribing. Half of the patients continued receiving PPIs at discharge without a documented indication.

\section{Conclusion}

Our findings indicated a high prevalence of inappropriate prescribing of PPIs as SUP for non-ICU patients. Interventions to reduce the unnecessary use of PPIs in Malaysian hospital settings are desperately required. The need for national criteria that address the proper indications and dosing regimens for PPIs as SUP in ICU and non-ICU patients is high.

This is a preview of subscription content, $\underline{\log } \underline{\text { in }}$ to check access.

\section{Access options}

Buy article PDF

$\underline{\text { Rent this article via DeepDyve. }}$

\section{$39,95 €$}

Price includes VAT for Malaysia

Instant access to the full article PDF.

Learn more about Institutional subscriptions

\section{References}

1. 1.

Plummer MP, Blaser AR, Deane AM. Stress ulceration: prevalence, pathology and association with adverse outcomes. Crit Care. 2014;18(2):213.

We use cookies to personalise content and ads, to provide social media features and to analyse our traffic. We also share information about your use of our site with our social media, advertising and

analytics partners in accordance with our Privacy Statement. You can manage your preferences in Manage Cookies. 
4. 4.

Toews I, George AT, Peter JV, et al. Interventions for preventing upper gastrointestinal bleeding in people admitted to intensive care units. Cochrane Database Syst. Rev. 2018;6(6):CD008687.

5. 5 .

Liu Y, Li D, Wen A. Pharmacologic prophylaxis of stress ulcer in non-ICU patients: a systematic review and network meta-analysis of randomized controlled trials. Clin Ther. 2020;48(3):488-98.

\section{$\underline{\text { CAS Article Google Scholar }}$}

6. 6 .

Oh AL, Tan AG, Phan HS, et al. Indication of acid suppression therapy and predictors for the prophylactic use of proton-pump inhibitors vs. histamine-2 receptor antagonists in a Malaysian tertiary hospital. Pharm Pract (Granada). 2015;13:1-6.

\section{$\underline{\text { Article Google Scholar }}$}

7. 7.

Alhazzani W, Alenezi F, Jaeschke RZ, et al. Proton pump inhibitors versus histamine 2 receptor antagonists for stress ulcer prophylaxis in critically ill patients: a systematic review and meta-analysis.

Crit Care Med. 2013;41:693-705.

\section{$\underline{\text { CAS }} \underline{\text { Article }} \underline{\text { Google Scholar }}$}

8. 8 .

ASHP therapeutic guidelines on stress ulcer prophylaxis. ASHP Commission on Therapeutics and approved by the ASHP board of directors on November 14, 1998. Am J Health Syst Pharm.

1999;56(4):347-79.

9. 9.

Ye ZK, Liu Y, Cui XL, et al. Critical appraisal of the quality of clinical practice guidelines for stress ulcer prophylaxis. PLoS One. 2016;11(5):e0155020.

\section{$\underline{\text { Article Google Scholar }}$}

10. 10 .

Stanford Hospital: pharmacy department policies and procedures. Medication monitoring: stress ulcer prophylaxis clinical guidelines. Stanford, CA: Stanford Hospital Clinics; 2015.

We use cookies to personalise

content and ads, to provide social

media features and to analyse our

traffic. We also share information

about your use of our site with our

social media, advertising and

> Manage Cookies

analytics partners in accordance

with our Privacy Statement. You can

manage your preferences in

Manage Cookies. 
13. 13.

Alnezary F, Crossman R, Alatawi Y, et al. The appropriateness of proton pump inhibitors usage in nonintensive care unit patients: a retrospective cross sectional study. Lat Am J Pharm. 2019;38:230-5.

\section{$\underline{\text { Google Scholar }}$}

14. 14 .

Farrell CP, Mercogliano G, Kuntz CL. Overuse of stress ulcer prophylaxis in the critical care setting and beyond. J Crit Care. 2010;25:214-20.

\section{$\underline{\text { Article }} \underline{\text { Google Scholar }}$}

15. 15 .

Gupta R, Garg P, Kottoor R, et al. Overuse of acid suppression therapy in hospitalized patients. South Med J. 2010;103:207-11.

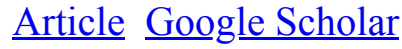

16. 16.

Buendgens L, Bruensing J, Matthes M, et al. Administration of proton pump inhibitors in critically ill medical patients is associated with increased risk of developing Clostridium difficile-associated diarrhea. J Crit Care. 2014;29(4):696.e11-5.

\section{$\underline{\text { CAS }} \underline{\text { Article }} \underline{\text { Google Scholar }}$}

17. 17.

Sasabuchi Y, Matsui H, Lefor AK, et al. Risks and benefits of stress ulcer prophylaxis for patients with severe sepsis. Crit Care Med. 2016;44(7):e464-9.

\section{$\underline{\text { Article }} \underline{\text { Google Scholar }}$}

18. 18.

Elnaem MH, Mohamed MHN, bin Nazar AH. Evaluation of proton pump inhibitors prescribing among non-critically ill hospitalized patients in a Malaysian tertiary hospital. J Appl Pharm Sci. 2017;7:77-83.

\section{$\underline{\text { CAS }} \underline{\text { Google Scholar }}$}

19. 19.

Fah TR, Jun TY, Yan P, et al. Appropriateness of proton pump inhibitors prescription in patients admitted to a Malaysian tertiary hospital. Int J Public Health Res. 2019;9:1043-50.

\footnotetext{
$r \sim \sim \sim 1 \sim C_{n} \ln \sim 1 \cdots$

We use cookies to personalise content and ads, to provide social media features and to analyse our traffic. We also share information about your use of our site with our social media, advertising and analytics partners in accordance with our Privacy Statement. You can manage your preferences in Manage Cookies.
} > Manage Cookies 
$\underline{\text { CAS PubMed Google Scholar }}$

22. 22 .

Alqudah MAY, Al-azzam S, Alzoubi K, et al. Overuse of proton pump inhibitors for stress ulcer prophylaxis in Jordan. Int J Clin Pharmacol Ther. 2016;54(8):597-602.

\section{$\underline{\text { CAS }} \underline{\text { Article }} \underline{\text { Google Scholar }}$}

23. 23.

Malhis A, Alghamdi T, Alfandi R, et al. Appropriateness of acid-suppressing agents for stress ulcer prophylaxis in non-intensive care unit setting in Saudi Arabia. J Pharm Bioallied Sci. 2019;11(1):96-101.

\section{$\underline{\text { Article Google Scholar }}$}

24. 24.

Sakata Y, Tsuruoka N, Takedomi H, et al. A study on the status of proton pump inhibitor prescriptions using diagnosis procedure combination data in Japan. Digestion. 2019;101:308-15.

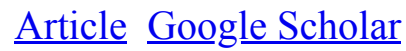

25. 25 .

Nehra AK, Alexander JA, Loftus CG, et al. Proton pump inhibitors: review of emerging concerns. Mayo Clin Proc. 2018;93:240-6.

\section{$\underline{\text { CAS }} \underline{\text { Article }} \underline{\text { Google Scholar }}$}

26. 26.

Eusebi LH, Rabitti S, Artesiani ML, et al. Proton pump inhibitors: risks of long-term use. J Gastroenterol Hepatol. 2017;32:1295-302.

\section{Article Google Scholar}

27. 27.

Mohamad MS, Shamsuddin N, Tan KM. Appropriateness of stress ulcer prophylaxis among older adults admitted to general medical wards in a university hospital. Eur Geriatr Med. 2015;6:119-23.

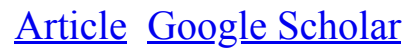

28. 28 .

Fick DM, Semla TP, Steinman M, et al. American Geriatrics Society 2019 updated AGS Beers criteria ${ }^{\circledR}$ for potentially inappropriate medication use in older adults. J Am Geriatr Soc. 2019;67(4):674-94.

We use cookies to personalise content and ads, to provide social media features and to analyse our traffic. We also share information about your use of our site with our social media, advertising and > Manage Cookies analytics partners in accordance with our Privacy Statement. You can manage your preferences in Manage Cookies. 
PubMed PubMed Central Google Scholar

31. 31 .

Joint Formulary Committee. Proton pump inhibitors. British National Formulary, 73rd ed. London: British Medical Association and Royal Pharmaceutical Society of Great Britain; 2018. p. 77-82.

32. 32 .

Tamblyn R, Huang A, Perreault R, et al. The medical office of the 21st century (MOXXI): effectiveness of computerized decision-making support in reducing inappropriate prescribing in primary care. CMAJ. 2003;169:549-56.

\section{$\underline{\text { PubMed }} \underline{\text { PubMed Central Google Scholar }}$}

33. 33.

Raebel MA, Charles J, Dugan J, et al. Randomized trial to improve prescribing safety in ambulatory elderly patients. J Am Geriatr Soc. 2007;55:977-85.

\section{$\underline{\text { Article Google Scholar }}$}

34. 34 .

Curtain C, Peterson GM, Tenni P, et al. Outcomes of a decision support prompt in community pharmacydispensing software to promote step-down of proton pump inhibitor therapy. Br J Clin Pharmacol. $2011 ; 71: 780-4$.

\section{$\underline{\text { Article }} \underline{\text { Google Scholar }}$}

35. 35 .

Freedberg DE, Salmasian H, Abrams JA, et al. Orders for intravenous proton pump inhibitors after implementation of an electronic alert. JAMA Intern Med. 2015;175(3):452-4.

$\underline{\text { Article }} \underline{\text { Google Scholar }}$

Download references $\underline{\underline{ }}$

\section{Acknowledgements}

The authors would like to thank Ahmad Faris, Saiful Bahari, Marsya Aida, Fathiatul Fiqah, Izzati, Hazirah Hidayah, and Anis Zulaikha from Rx16 for helping in collecting the data.

\section{Author information}

We use cookies to personalise content and ads, to provide social media features and to analyse our traffic. We also share information about your use of our site with our social media, advertising and analytics partners in accordance with our Privacy Statement. You can manage your preferences in Manage Cookies. 
1. Muhammad Eid Akkawi

View author publications

You can also search for this author in PubMed Google Scholar

2. Mohamed Hassan Elnaem

View author publications

You can also search for this author in PubMed Google Scholar

\section{Corresponding author}

Correspondence to $\underline{\text { Muhammad Eid Akkawi. }}$

\section{Ethics declarations}

\section{Conflicts of Interest}

Muhammad Eid Akkawi and Mohamed Hassan Elnaem have no conflicts of interest that are directly relevant to the content of this article.

\section{Funding}

No sources of funding were used to conduct this study or prepare this manuscript.

\section{Consent to participate and consent to publication}

Not applicable.

\section{Code availability}

Not applicable.

\section{Availability of data and material}

Data and materials are available upon request.

\section{Ethical Approval}

This study protocol was approved by the International Islamic University Malaysia Research Ethics Committee (IREC 2019-223) and the clinical research center (CRC) of the hospital.

\section{Author contributions}

We use cookies to personalise content and ads, to provide social media features and to analyse our traffic. We also share information about your use of our site with our social media, advertising and > Manage Cookies analytics partners in accordance with our Privacy Statement. You can manage your preferences in Manage Cookies. 
Check for

updates

\section{Cite this article}

Akkawi, M.E., Elnaem, M.H. Evaluation of the prescribing of proton pump inhibitors as stress ulcer prophylaxis for non-ICU patients in a Malaysian tertiary hospital. Drugs Ther Perspect (2020). https://doi.org/10.1007/s40267-020-00770-6

\section{Download citation $\underline{\underline{ }}$}

- Published: 31 August 2020

- DOI: https://doi.org/10.1007/s40267-020-00770-6

\section{Access options}

Buy article PDF

\section{$39,95 €$}

Price includes VAT for Malaysia

Instant access to the full article PDF.

$\underline{\text { Rent this article via DeepDyve. }}$

Learn more about Institutional subscriptions

- Sections

- References

- $\underline{\text { Abstract }}$

- References

- Arknnixladramente

We use cookies to personalise content and ads, to provide social media features and to analyse our traffic. We also share information about your use of our site with our social media, advertising and analytics partners in accordance with our Privacy Statement. You can manage your preferences in Manage Cookies. 
1. Plummer MP, Blaser AR, Deane AM. Stress ulceration: prevalence, pathology and association with adverse outcomes. Crit Care. 2014;18(2):213.

\section{Article Google Scholar}

2. Buendgens L, Koch A, Tacke F. Prevention of stress-related ulcer bleeding at the intensive care unit: risks and benefits of stress ulcer prophylaxis. World J Crit Care Med. 2016;5(1):57-64.

\section{$\underline{\text { Article Google Scholar }}$}

3. Madsen KR, Lorentzen K, Clausen N, et al. Danish Society of Intensive Care Medicine; Danish Society of Anesthesiology and Intensive Care Medicine. Guideline for stress ulcer prophylaxis in the intensive care unit. Dan Med J. 2014;61(3):C4811.

\section{$\underline{\text { PubMed Google Scholar }}$}

4. Toews I, George AT, Peter JV, et al. Interventions for preventing upper gastrointestinal bleeding in people admitted to intensive care units. Cochrane Database Syst. Rev. 2018;6(6):CD008687.

5. Liu Y, Li D, Wen A. Pharmacologic prophylaxis of stress ulcer in non-ICU patients: a systematic review and network meta-analysis of randomized controlled trials. Clin Ther. 2020;48(3):488-98.

\section{$\underline{\text { CAS }} \underline{\text { Article Google Scholar }}$}

6. Oh AL, Tan AG, Phan HS, et al. Indication of acid suppression therapy and predictors for the prophylactic use of proton-pump inhibitors vs. histamine-2 receptor antagonists in a Malaysian tertiary hospital. Pharm Pract (Granada). 2015;13:1-6.

\section{$\underline{\text { Article Google Scholar }}$}

7. Alhazzani W, Alenezi F, Jaeschke RZ, et al. Proton pump inhibitors versus histamine 2 receptor antagonists for stress ulcer prophylaxis in critically ill patients: a systematic review and meta-analysis.

Crit Care Med 2012.41.693-705

We use cookies to personalise content and ads, to provide social media features and to analyse our traffic. We also share information about your use of our site with our social media, advertising and > Manage Cookies analytics partners in accordance with our Privacy Statement. You can manage your preferences in Manage Cookies. 
10. Stanford Hospital: pharmacy department policies and procedures. Medication monitoring: stress ulcer prophylaxis clinical guidelines. Stanford, CA: Stanford Hospital Clinics; 2015.

11. Guillamondegui OD, Gunter OL Jr, Bonadies JA, et al. EAST Practice Management Guidelines Committee. Practice management guideline for stress ulcer prophylaxis. Chicago: Eastern Association for the Surgery of Trauma; 2008.

\section{$\underline{\text { Google Scholar }}$}

12. Savarino V, Dulbecco P, de Bortoli N, et al. The appropriate use of proton pump inhibitors (PPIs): need for a reappraisal. Eur J Intern Med. 2017;37:19-24.

\section{$\underline{\text { CAS Article Google Scholar }}$}

13. Alnezary F, Crossman R, Alatawi Y, et al. The appropriateness of proton pump inhibitors usage in nonintensive care unit patients: a retrospective cross sectional study. Lat Am J Pharm. 2019;38:230-5.

\section{$\underline{\text { Google Scholar }}$}

14. Farrell CP, Mercogliano G, Kuntz CL. Overuse of stress ulcer prophylaxis in the critical care setting and beyond. J Crit Care. 2010;25:214-20.

\section{$\underline{\text { Article Google Scholar }}$}

15. Gupta R, Garg P, Kottoor R, et al. Overuse of acid suppression therapy in hospitalized patients. South Med J. 2010;103:207-11.

\section{$\underline{\text { Article Google Scholar }}$}

16. Buendgens L, Bruensing J, Matthes M, et al. Administration of proton pump inhibitors in critically ill medical patients is associated with increased risk of developing Clostridium difficile-associated diarrhea. J Crit Care. 2014;29(4):696.e11-5.

\section{$\underline{\text { CAS }} \underline{\text { Article Google Scholar }}$}

17. Sasabuchi Y, Matsui H, Lefor AK, et al. Risks and benefits of stress ulcer prophylaxis for patients with severe sepsis. Crit Care Med. 2016;44(7):e464-9.

\section{Article Google Scholar}

18. Elnaem MH, Mohamed MHN, bin Nazar AH. Evaluation of proton pump inhibitors prescribing among non-critically ill hospitalized patients in a Malaysian tertiary hospital. J Appl Pharm Sci. 2017;7:77-83.

\section{$\underline{\text { CAS }} \underline{\text { Google Scholar }}$}

19. Fah TR, Jun TY, Yan P, et al. Appropriateness of proton pump inhibitors prescription in patients admitted to a Malaysian tertiary hospital. Int J Public Health Res. 2019;9:1043-50.

\footnotetext{
We use cookies to personalise content and ads, to provide social media features and to analyse our traffic. We also share information about your use of our site with our social media, advertising and analytics partners in accordance with our Privacy Statement. You can manage your preferences in Manage Cookies.
} > Manage Cookies 


\section{$\underline{\text { CAS }}$ Article Google Scholar}

23. Malhis A, Alghamdi T, Alfandi R, et al. Appropriateness of acid-suppressing agents for stress ulcer prophylaxis in non-intensive care unit setting in Saudi Arabia. J Pharm Bioallied Sci. 2019;11(1):96-101.

\section{$\underline{\text { Article Google Scholar }}$}

24. Sakata Y, Tsuruoka N, Takedomi H, et al. A study on the status of proton pump inhibitor prescriptions using diagnosis procedure combination data in Japan. Digestion. 2019;101:308-15.

\section{$\underline{\text { Article }} \underline{\text { Google Scholar }}$}

25. Nehra AK, Alexander JA, Loftus CG, et al. Proton pump inhibitors: review of emerging concerns. Mayo Clin Proc. 2018;93:240-6.

\section{$\underline{\text { CAS Article Google Scholar }}$}

26. Eusebi LH, Rabitti S, Artesiani ML, et al. Proton pump inhibitors: risks of long-term use. J Gastroenterol Hepatol. 2017;32:1295-302.

\section{Article Google Scholar}

27. Mohamad MS, Shamsuddin N, Tan KM. Appropriateness of stress ulcer prophylaxis among older adults admitted to general medical wards in a university hospital. Eur Geriatr Med. 2015;6:119-23.

\section{$\underline{\text { Article }} \underline{\text { Google Scholar }}$}

28. Fick DM, Semla TP, Steinman M, et al. American Geriatrics Society 2019 updated AGS Beers criteria ${ }^{\circledR}$ for potentially inappropriate medication use in older adults. J Am Geriatr Soc. 2019;67(4):674-94.

\section{Article Google Scholar}

29. Wedemeyer RS, Blume H. Pharmacokinetic drug interaction profiles of proton pump inhibitors: an update. Drug Saf. 2014;37:201-11.

\section{$\underline{\text { CAS Article Google Scholar }}$}

30. Perwaiz M. Inappropriate use of intravenous PPI for stress ulcer prophylaxis in an inner city community hospital. J Clin Med Res. 2010;2:215-9.

\section{$\underline{\text { PubMed PubMed Central Google Scholar }}$}

31. Joint Formulary Committee. Proton pump inhibitors. British National Formulary, 73rd ed. London: British Medical Association and Royal Pharmaceutical Society of Great Britain; 2018. p. 77-82.

32. Tamblyn R, Huang A, Perreault R, et al. The medical office of the 21st century (MOXXI): effectiveness of computerized decision-making support in reducing inappropriate prescribing in primary care. CMAJ. 2003;169:549-56.

We use cookies to personalise content and ads, to provide social media features and to analyse our traffic. We also share information about your use of our site with our social media, advertising and > Manage Cookies $\checkmark$ OK analytics partners in accordance with our Privacy Statement. You can manage your preferences in Manage Cookies. 
35. Freedberg DE, Salmasian H, Abrams JA, et al. Orders for intravenous proton pump inhibitors after implementation of an electronic alert. JAMA Intern Med. 2015;175(3):452-4.

Article Google Scholar

Over 10 million scientific documents at your fingertips

Switch Edition

- Academic Edition

- Corporate Edition

- $\underline{\text { Home }}$

- Impressum

- Legal information

- Privacy statement

- California Privacy Statement

- How we use cookies

- Manage cookies/Do not sell my data

- Accessibility.

- $\underline{\text { Contact us }}$

Not logged in - 210.48.221.4

8354 Springerlink Malaysia consortium (3000519906) - SpringerLink Malaysia eJournal Consortium - Higher Education (3000916360) - 10122 SpringerLink Malaysia eJourna Consortium - Higher Education (3000716851)

- International Islamic University Malaysia (IIUM) (2000621865) - 4972 SpringerLink Malaysia eBook Consortium-2009-2010 copyright (3000134874) - 6816 SpringerLink Malaysia eJournal Consortium - Higher Education (3000155375)

\section{Springer Nature SPRINGER NATURE}

(C) 2020 Springer Nature Switzerland AG. Part of Springer Nature.

\section{Muhammad Eid Akkawi}

View ORCID ID profile

We use cookies to personalise content and ads, to provide social media features and to analyse our traffic. We also share information about your use of our site with our social media, advertising and analytics partners in accordance with our Privacy Statement. You can manage your preferences in Manage Cookies. 


\section{Mohamed Hassan Elnaem}

View ORCID ID profile

- Department of Pharmacy Practice, Faculty of Pharmacy, International Islamic University Malaysia, Jalan Sultan Ahmad Shah, Bandar Indera Mahkota, 25200, Kuantan, Pahang, Malaysia

- Quality Use of Medicines Research Group, Faculty of Pharmacy, International Islamic University Malaysia, Kuantan, Malaysia

$\underline{\text { View author publications }}$

You can also search for this author in PubMed Google Scholar

Close

We use cookies to personalise content and ads, to provide social media features and to analyse our traffic. We also share information about your use of our site with our social media, advertising and analytics partners in accordance with our Privacy Statement. You can manage your preferences in Manage Cookies. 